\title{
THE ROLE OF THE STUDENT TEACHER MUSYAWARAH (MGMP) IN IMPROVING THE UNDERSTANDING OF PKN TEACHERS ABOUT HUMAN RIGHTS (HAM)
}

\author{
Aries Abbas \\ Islamic University of Jakarta \\ Email: ariesabbas@paramout.co.id \\ Marhamah Marhamah \\ Islamic University of Jakarta \\ Email: marhamahsyarif2@gmail.com
}

\begin{abstract}
Abstrak
Menghormati pandangan anak merupakan prinsip fundamental yang berkaitan dengan semua aspek pelaksanaan dan interpretasi pasal-pasal konvensi lainnya. Pandangan setiap anak perlu diperhatikan dalam pengambilan keputusan yang akan mempengaruhi kehidupan dan perkembangan anak. Faktor-faktor yang dapat mempengaruhi pemahaman guru PKn, adanya sosialisasi dengan sesama guru PKn, adanya komunikasi dua arah dengan anggota MGMP, adanya kesamaan persepsi dalam mengatasi siswa bermasalah, adanya kolaborasi saat menyelesaikan masalah yang dihadapi siswa dan kerjasama dapat dilakukan dengan guru PAI, guru BK, guru PKn harus mengetahui atau benar-benar memahami peran dan tujuan pembelajaran PKn, karena mata pelajaran PKn mempunyai peran dalam pendidikan untuk mengembangkan pengembangan karakter melalui peran guru PKn. Sesuai dengan salah satu misi mata pelajaran PKn paradigma baru yaitu sebagai pendidikan karakter. Mata pelajaran PKn sebagai salah satu mata pelajaran yang memiliki muatan dalam pendidikan akhlak dan kebangsaan, merupakan mata pelajaran yang wajib mengikuti proses pendidikan karakter melalui peran guru PKn. Dengan menerapkan metode pembelajaran yang tepat dan didukung oleh seluruh jajaran di lembaga pendidikan tersebut, guru PKn dapat berinisiatif menjadi penggerak program pembelajaran karakter. Sebagai luaran pembelajaran PKn ini akan lahir generasi yang memiliki sumber daya manusia yang benar-benar berkualitas sesuai dengan tujuan pendidikan nasional.
\end{abstract}

Kata Kunci: PKn, Mata Pelajaran Yang Berisi dalam Pendidikan Moral dan Nasionalisme.

\begin{abstract}
Respecting children's views is a fundamental principle that relates to all aspects of the implementation and interpretation of other articles of the convention. Every child's views need to be considered in making decisions that will affect the child's life and development. Factors that can affect the understanding of Civics teachers, the existence of socialization with fellow Civics teachers, the existence of a two-way communication with MGMP members, the existence of shared perceptions in overcoming problematic students, the existence of collaboration when solving problems faced by students and cooperation can be carried out with teachers PAI, counseling teachers, Civics teachers must know or really understand the role and objectives of Civics learning, because Civics subjects have a role in education to develop character development through the role of Civics teachers. In accordance with one of the missions of the new paradigm Civics subject, namely as
\end{abstract}


character education. Civics as one of the subjects that have content in moral education and nationalism, is a subject that is obliged to take part in the character education process through the role of Civics teachers. By applying appropriate teaching methods and supported by all levels of personnel at these educational institutions, Civics teachers can take the initiative to be the driving force for the character learning program. As the output of this Civics learning, there will be a generation with truly quality human resources in accordance with the goals of national education.

Keywords: PKn, Subjects That Have Content in Moral Education and Nationalism.

\section{A. Introduction}

Professional teachers must understand complex matters such as the placement of human rights according to their respective portions in school. The government is seriously working on the competence of teachers who are considered to be weak through the Education Office, the Education Quality Assurance Agency (LPMP), and P4TK in the form of an empowerment program for Subject Teacher Conference (MGMP) at the primary and secondary education levels (SMP and SMA).

One of the crucial problems facing this nation is the low quality of education, which leads to the weak competitiveness of Human Resources (HR) and the low productivity of Indonesian people in general. The quality of education in Indonesia is still considered low by many circles

The problems faced by the education sector are very complex, one of which is problems related to substantial aspects such as teaching feasibility and the difficulty of implementing a competency-based curriculum. In the context of educational reform, teachers are a major element in the education process. The teacher's task is very complex, in addition to transferring knowledge and skills to students, the teacher also has the task of educating the development of all the potential of students so that they become mature and mature so that they are able to take part in the future.

Starting from the low competence of teachers, inadequate facilities, educational facilities and infrastructure, weak management elements at the education unit level, to the lack of participation of community elements in education delivery. All of these are a series of problems that require serious handling and a strong commitment from all parties to resolve them. Therefore, to improve the quality of education, systematic, comprehensive and consistent efforts are needed and touch on specific aspects.

Law of the Republic of Indonesia Number 14 of 2005 concerning Teachers and Lecturers, Government Regulation Number 19 of 2005 concerning National Education Standards, and Government Regulation Number 74 of 2008 concerning Teachers mandates that teachers are required to have a minimum academic qualification of S1 or D-IV, competence, and educator certificates. In addition, according to the development of science, technology and art, teachers must improve their competence an on going basis. 
In order for teacher coaching activities at KKG and MGMP to be more focused, it is necessary to formulate signs for the development and implementation of the KKG and MGMP. MGMP (Subject Teacher Conference) is a forum for professional activities for teachers of the same subject at the SMP/MTs/SMPLB, SMA/MA/SMALB, and SMK/MAK levels at the district/city level which consists of a number of teachers from a number of schools.

In this regard, in order for the process of improving academic qualifications and teacher competence to be programmed and carried out properly, an independent and professional teacher training forum is needed. Existing teacher training platforms, namely the Teacher Working Group (KKG) for SD/MI/SDLB teachers and Subject Teacher Deliberation (MGMP) for SMP/MTs/SMPLB, SMA/MA/SMALB, and SMK/MAK teachers are currently still has not been going well and still faces many obstacles. What is the existence, role and performance of the MGMP after obtaining legality from the local government. However, the role and performance of the MGMPs still have to await their existence. At least a pile of hope is devoted to the forum for professionalism of teachers at the SMP, SMA and SMK levels in an effort to improve the quality of education at the secondary level.

As we know, MGMP is a forum or forum for the professionalism of subject teachers in a district/city/sub-district/studio/school cluster. Its scope includes subject teachers at the public and private junior high school, senior high school and vocational high schools, both civil servants and private. Its working principle is a reflection of the "from, by and for teachers" activities of all schools. On this basis, the MGMP is a non-structural organization that is independent, based on kinship, and does not have hierarchical relationships with other institutions.

The objectives of the MGMP according to the Directorate General of Quality Improvement of Educators and Education Personnel (2008: 4) are:

1. Expanding teacher insights and knowledge in various matters, especially mastery of the substance of learning materials, preparation of syllabus, preparation of learning materials, learning strategies, learning methods, maximizing the use of learning facilities/infrastructure, utilizing learning resources, etc.

2. Provide opportunities for members of working groups or work deliberations to share experiences and provide mutual assistance and feedback.

3. Increase knowledge and skills, and adopt a more professional approach to learning for work group participants or work deliberations.

4. Empower and assist work group members in carrying out learning tasks at school.

5. Changing the work culture of working group members or working deliberations (increasing knowledge, competence and performance) and 
developing teacher professionalism through professional development activities at the KKG/MGMP level.

6. Improve the quality of the education and learning process which is reflected in the increase in learning outcomes of students.

7. Improve teacher competence through activities at the level. KKG/MGMP.

Based on this quote, the MGMP must be able to develop creativity and innovation in building cooperation between teachers, in increasing teacher professionalism, broadening the insight and knowledge of subject teachers in an effort to realize effective and efficient learning and developing a conducive classroom culture as a place for a fun learning process.

To face globalization, we need a non-physical struggle in accordance with our respective professions. This non-physical struggle requires educational activities for every Indonesian citizen in general and students as prospective scholars in particular, namely through Citizenship Education.

Based on this, civic education includes educating and directing this nation so that it wants to foster a sense of responsibility to itself and also to others, foster intelligence and of course respect or respect human rights as well as encourage all citizen participation.

Based on this, with that mind and conscience, humans have the freedom to decide their own behavior or actions. In addition, to balance this freedom, humans have the ability to be responsible for all the actions they do. Basic freedoms and basic rights are what are called human rights that are inherent in humans by nature as gifts from God Almighty. These rights cannot be denied.

Denial of this right means denying human dignity. Therefore, the state, government, or any organization has the obligation to recognize and protect the human rights of every human being without exception. This means that human rights must always be the starting point and goal in organizing the life of the community, nation and state. Mankind has it not because it is given to it by society or based on positive law, but solely based on its human dignity.

In this sense, even though everyone is born with a different skin color, gender, language, culture and nationality, he still has these rights. This is the universal nature of these rights. Apart from being universal, these rights are also inalienable. This means that no matter how bad the treatment has been experienced by a person or no matter how cruel someone's treatment is, he will not stop being a human being and therefore still has these rights. In other words, these rights are attached to him as a human being.

In line with the above view, the freedom of everyone is limited by the human rights of others. This means that everyone has the duty to recognize and respect the human rights of others. This obligation also applies to every organization at any level, especially the state and government. Thus, the state and government are responsible for respecting, protecting, defending and 
guaranteeing the human rights of every citizen and population without discrimination.

The obligation to respect human rights is reflected in the Preamble to the 1945 Constitution which animates the whole article. Some of the problems that exist in schools regarding the understanding of human rights, can be seen in indicators such as teachers who do not understand the rights of children to implement compulsory education for 12 (twelve years), so when there are children in schools who are naughty the teacher does not want to provide special guidance, so that teachers are visited by parents because they feel their children are not given the right to learn, in certain subjects such as mathematics the children feel afraid because they feel that the lessons are difficult and are added to the attitude of the teacher who is less friendly to students. so that this becomes a problem that teachers do not understand the child's right to receive knowledge from him so that the teacher should carry out a strategy to overcome this but instead makes the child afraid, this is the teacher's lack of understanding of human rights, the next problem is how the teacher reprimands too harshly towards students can cause displeasure on the part of parents, so that sometimes teachers are trapped by human rights violations until parents come to school and the authorities intervene. Another thing, in a phenomenon, many teachers are trapped in human rights problems with the problem of committing acts of rape to students, molesting students.

Based on the phenomenon of the problems described above, the role of MGMP is needed in cultivating knowledge about human rights in teachers so that teachers will not be trapped in human rights violations against students in schools, so with the phenomenon of such problems, researchers make a research study with title: "The Role of Subject Teacher Deliberation (MGMP) in Improving Understanding for Pkn Teachers about Human Rights (HAM). (Case Study on Junior High School MGMP in CiranjangSubdistrict, Cianjur Regency) ".

Based on the background above, the problem formulations in this study are:

1. What efforts have the MGMP made in order to increase the understanding of Civics teachers on human rights?

2. What factors influence Civics teachers' understanding of human rights in MGMP?

3. What is the role of the MGMP in increasing Civics teachers' understanding of human rights?

\section{B. Method of Research}

In general, the purpose of this study is to determine the efforts made by the MGMP in increasing the understanding of Civics teachers towards human rights by a series of activities carried out in MGMP and followed by Civics teachers, so 
that the activities in MGMP can be carried out in a sustainable manner in order to get optimal results.

With this, previous research is presented in order to know the similarities and differences between the previous research and the research that the researcher did. Raden Roro Suci Nurdianti (2013) The Effect of Subject Teacher Deliberative Management (MGMP) on Professional Competence and Competency of Pedagogic Teachers and Its Implications for the Performance of Teachers in Economics Subjects in Public High Schools in Bandung City, thesis, Universitas Pendidikan Indonesia. The background of the problem with the findings of the 2012 Early Competency Test results in the previous words, namely the average value of 42.5 and the highest value which only reaches 50.1 . Highly influenced by competency factors, and one of the factors that affect competence, namely the continuous professional development program through MGMP activities. The composition of the influence of the Implementation of Economic MGMP on Professional Competence and Pedagogical Competence and its implications for the costs of economic teachers in SMA Negeri in Bandung. The sample selection was carried out by means of proportional random sampling analysis method.

The purpose of this study was to measure the impact of the Effectiveness of the Economic Teacher Council on Professional Competence and Pedagogic Competence and also implications for the performance of SMA Ekonomi teachers in Bandung. The population in this study were economics teachers in high schools in Bandung who were engaged in the Teacher Council. Samples were taken through proportional random sampling method. Data obtained from primary sources through questionnaires, and information from the Economic Teacher Council.

The analysis of the research results shows the effectiveness of the Board of Teachers (X) has a positive effect on Professional Competence (Y1) and Pedagogic Competence (Y2). This means that the effective implementation of the Teacher Council (MGMP), will affect Professional Competence and Pedagogical Competence. In addition, there is also a positive influence between the Effectiveness of the Teacher Council (X), Professional Competence (Y1) and Pedagogic Competence (Y2) on Teacher Performance (Y3). There are direct and indirect influences from the effectiveness of the Teacher Council to Teacher Performance. The effect of the effect on teacher performance is indirect through the variables of Professional Competence (Y1) and Pedagogic Competence (Y2). The implication of this research is that all parts involved in the education process, especially teachers, schools, and the government further improve the teacher councils built by teachers, due to several types of teacher competency development and also to improve their performance for better education. In addition, teacher motivation to participate in programs organized by the teacher council must be increased. Keywords: Teacher Effectiveness Board (MGMP), Professional Competence, Pedagogic Competence, Teacher Performance. 
Azizah Hidayatul (2012) The Role of MGMP Management in improving the professionalism of Islamic Education Teachers in Semarang City. Thesis. IAIN Walisongo Semarang. This research is motivated by the problem, namely the lack of understanding of the management of MGMP PAI SMA in the city of Semarang. The focus of the research is: 1) How is the implementation of the management of Islamic Islamic education high school MGMP in the city of Semarang, 2) How is the competence of PAI SMA teachers in the city of Semarang, 3) How MGMP management can contribute to improving the competence and professionalism of Islamic Education teachers.

This research was conducted at the MGMP PAI SMA in the city of Semarang. The nature of this research is qualitative using a management science approach. Data collection was carried out using in-depth observation methods, participating interviews and documentation, where the chairman and secretary of the MGMP PAI were key informants and researchers as key instruments in obtaining data. Data collection was carried out from April 2012 to May 2012 at SMA Negeri 3 Semarang I. Data analysis was carried out in a descriptive qualitative manner with an interactive model.

Conduct training on the use of ICT as a model in learning. Thus it can be concluded that the role of MGMP management in improving the professionalism of Islamic Education teachers has a very important role so that the involvement of all PAI SMA teachers is expected to be in accordance with the objectives of implementing the MGMP.

Management Functions The discussion of management activities can be found in many scientific literature. The following descriptions do not intend to carry out a similar discussion. In other words, this description is focused on the discussion of MGMP management that supports the implementation of management, while management as a process of implementing administration in an organization is a continuous activity starting from planning to assessment. In the process of implementing education management functions have tasks that must be completed, in management we know them as functions. First, Planning. Planning is essentially a decision-making activity about what goals it will achieve, what actions will be taken in order to achieve these goals or objectives and who will carry out these tasks. As with other management functions, the term planning also has various meanings according to the opinion of management experts.Sujana argues that planning is a systematic process in making decisions about actions to be taken in the future.

It is called systematic because planning is carried out using certain principles. These principles include the decision-making process, the use of scientific knowledge and techniques, and organized action or activity.

Second, Organizing. Throughout its development, organizing or as a management function, has different meanings. This understanding is caused by differences in the background of the expertise of the experts who provide that 
understanding, and is influenced by environmental conditions in implementing the organizing function. The term organization can be interpreted into two definitions, namely: in a static sense, organization as a forum for cooperation.

The similarity lies in the management of the Subject Teacher Deliberation and the teacher's pedagogical competence, which is the difference, namely in the subjects studied. This study examines the MGMP of Islamic Religious Education, while the research conducted by the MGMP Pkn researchers on the understanding of human rights.

Nanik Sri Setyani (2012) Improvement of MGMP Organizational Dynamics through Adult Learning-Based Assistance (Case in Economic MGMP at SMA Jombang District).Dissertation of Economic Education Program, Post-Graduate, State University of Malang.

The development or improvement of teacher professional abilities must be based on the real needs or problems faced by teachers. In order for the process of improving the professionalism or quality of the teacher to be well programmed, it is necessary to have an independent and professional teacher training forum.

\section{Discussion}

\section{MGMP Improve Civics Teachers' Understanding of Human Rights}

Based on the results of interviews and observations regarding the efforts made by the MGMP in improving Civics teachers' understanding of human rights, the introduction of human rights should have been instilled in the family. This means that the family has more authority (read responsibility) to instill human rights in children. The child (human) has the right to live. That is, he is a free person to have opinions without interference and to seek, receive, and convey information and ideas through any media without knowing any boundaries.

Based on the above, from the results of the research and the theory used, there is relevance that every student has the right to get teaching and attention from teachers, both smart students, especially those who are less smart, still teachers must provide teaching and pay attention to students by not committing acts of violence and discrimination. , because it can violate human rights.

Respecting children's views is a fundamental principle that relates to all aspects of the implementation and interpretation of other articles of the convention, every child's views need to be considered in making decisions that will affect the child's life and development.

Efforts were made, the MGMP created a special program of meetings with Civics teachers to discuss problems faced by students in their respective schools, Civics teachers reported problems faced in schools and then presented them in MGMP deliberations, this was done so that teachers received input from teachers others so that when making decisions do not violate the rules. 


\section{Factors Affecting Civics Teachers' Understanding of Human Rights}

Factors that can affect the understanding of Civics teachers, the existence of socialization with fellow Civics teachers, the existence of a two-way communication with MGMP members, the existence of shared perceptions in overcoming problematic students, the existence of collaboration when solving problems faced by students and cooperation can be carried out with teachers PAI, counseling teachers, Civics teachers must know or really understand the role and objectives of Civics learning, because Civics subjects have a role in education to develop character development through the role of Civics teachers. In accordance with one of the missions of the new paradigm Civics subject, namely as character education. Civics as one of the subjects that have content in moral education and nationalism, is a subject that must take part in the character education process through the role of Civics teachers. By applying appropriate teaching methods and supported by all levels of personnel at these educational institutions, Civics teachers can take the initiative to be the driving force for the character learning program. As the output of this Civics learning, there will be a generation with truly quality human resources in accordance with the goals of national education.

The results of this study, related to the objectives of civic education held in Indonesia, professionally Civics teachers must really master the application of human rights properly and correctly because if it violates human rights is a violation and can have fatal consequences, rights and obligations are politely honest and democratic as well as being sincere as an educated citizen in his life as a responsible citizen of the Republic of Indonesia. Mastering knowledge and understanding of various basic problems of the life of the nation and state that will be resolved with the application of ideas based on Pancasila insight into the archipelago and national resilience critically and responsibly. Cultivate attitudes and behavior in accordance with the values of struggle and patriotism that love the country.

\section{The Role of The MGMP in Improving Civics Teachers' Understanding of Human Rights}

The role of MGMP in improving Civics teachers' understanding of human rights, namely MGMP is a forum for socialization in increasing teacher competence through routine activities that are carried out once a month. Furthermore, the MGMP can assist in increasing the understanding of Civics materials including human rights (HAM).

MGMP activities make it easier to instill communication either directly face to face with one's profession or via electronic media, such as SMS, email, Facebook and others in improving Civic Education materials including human rights, Civics MGMP has a role as a place to share experiences about the obstacles faced and the difficulties in delivering Civics subject matter including human rights, so sharing with teachers from other schools who have been successful. 
Law of the Republic of Indonesia Number 14 of 2005 concerning Teachers and Lecturers, Government Regulation Number 19 of 2005 concerning National Education Standards, and Government Regulation Number 74 of 2008 concerning Teachers mandates that teachers are required to have minimum academic qualifications of S1 or D-IV, competence, and educator certificate.

In addition, according to the development of science, technology and art, teachers must improve their competence on an ongoing basis. In order for teacher coaching activities in the KKG and MGMP to be more focused, signs need to be drawn up

Development and implementation of KKG and MGMP. MGMP (Subject Teacher Conference) is a forum for professional activities for teachers of the same subject at the SMP/MTs/SMPLB, SMA/MA/SMALB, and SMK/MAK levels at the district/city level which consists of a number of teachers from a number of schools.

According to Baedhowi, MGMP is: The KKG or MGMP organization is the minimum standard arrangement regarding the management structure, membership, and administrative legality of the KKG or MGMP. KKG or MGMP financing is the minimum standard regulation regarding the source of funds, usage, and accountability for the use of KKG or MGMP funds.

KKG or MGMP management is a minimum standard setting on the process of implementing the KKG or MGMP program. The development of the KKG or MGMP is an effort to provide added value from the current state of the KKG or MGMP, including the inputs, processes, and outputs resulting from KKG or MGMP activities.

Monitoring and Evaluation of the KKG or MGMP is a process to obtain an overview of the activities and performance of the KKG or MGMP in the management and implementation of activities in a consistent and sustainable manner.

a. Expanding teacher insights and knowledge in various matters, especially mastery of the substance of learning materials, preparation of syllabus, preparation of learning materials, learning strategies, learning methods, maximizing the use of learning facilities/infrastructure, utilizing learning resources, etc.

b. Provide opportunities for members of working groups or work deliberations to share experiences and provide mutual assistance and feedback.

c. Increase knowledge and skills, and adopt a renewal approach in more professional learning for participants in work groups or work deliberations.

d. Empower and assist work group members in carrying out learning tasks at school. 
e. Changing the work culture of working group members or work deliberations (increasing knowledge, competence and performance) and developing teacher professionalism through professional development activities at the KKG/MGMP level.

f. Improve the quality of the education and learning process which is reflected in the increase in learning outcomes of students.

g. Improve teacher competence through activities at the level. KKG/MGMP.

Through MGMP, of course as a Civics teacher can maintain the honor of children as humans, which should be respected by the term humanizing humans as humans. Even though in reality each child has a different character. It is the teacher's obligation to pay full attention to children, always provide cleanliness and tidiness of dress, motivate learning, including discipline to obey school rules.

\section{Conclusion}

Civics MGMP strives to increase Civics teachers knowledge of human rights, this is done through comparative study activities for Civics teachers to places that are related to the implementation of human rights, seminars related to human rights violations. So that with these activities can minimize human rights violations committed either by the teacher itself or by students. Furthermore, the routine meeting program with Civics teachers specifically for discussion related to problems faced by students in their respective schools, then Civics teachers report the problems faced at school and then present them at the MGMP deliberation.

\section{References:}

Law of the Republic of Indonesia Number 14 of 2005 concerning Teachers and Lecturers, Government Regulation Number 19 of 2005 concerning National Education Standards, and Government Regulation Number 74 of 2008 concerning Teachers mandates that teachers are required to have minimum academic qualifications of S1 or D-IV.

Law of the Republic of Indonesia Number 14 of 2005 concerning Teachers and Lecturers. AzizahHidayatul (2012) The Role of MGMP Management in improving the professionalism of Islamic Education Teachers in Semarang City. Thesis. IAIN Walisongo Semarang.

Nanik Sri Setyani (2012) Improvement of MGMP Organizational Dynamics through Adult Learning-Based Assistance (Case in Economic MGMP at SMA Jombang District). Dissertation of Economic Education Program, Post-Graduate, State University of Malang Raden.

Roro Suci Nurdianti. (2013) The Influence of Subject Teacher Deliberative Management (MGMP) on Professional Competence and Competency of Pedagogic Teachers and Its Implications for the Performance of Teachers in Economics Subjects in Public High Schools in Bandung, thesis, UniversitasPendidikan Indonesia. 